\title{
Analisis Faktor-faktor yang Mempengaruhi Penerimaan dan Penggunaan Mobile Payment pada Teknologi Pembayaran Gopay
}

\author{
Wilbert Sinclair ${ }^{* 1}$, Lailan Maulia ${ }^{2}$, Tina Novianti Sitanggang ${ }^{3}$ \\ Universitas Prima Indonesia ${ }^{1,2,3}$ \\ wilbert_sinclair99@ rocketmail.com ${ }^{1)}$, lailanmaulia@yahoo.com ${ }^{2)}$, tinapaulus7371@ @mail.com ${ }^{3)}$
}

*Corresponding Author

Submitted: January 4, 2021

Accepted: January 19, 2021

Published: February 11, 2021

\begin{abstract}
This study aims to determine the factors that influence the acceptance and the use of mobile payments in GOPAY payment technology by integrating the Technology Acceptance Model (TAM) theory, mobile payment characteristics, trust and security and privacy. The research method used is a survey method. The sample of this research is GOPAY users in Faculty of Economics at Prima Indonesia University, as many as 222 (two hundred and twenty two) respondents through an online questionnaire. Data analysis using Smart Partial Least Square (PLS) 3.0. The results of this study can be concluded that the factors that influence the acceptance and the use of mobile payments on GOPAY payment technology are mobile payment characteristics, trust and security and privacy which are not supported in this study. GOPAY has the characteristics of mobility, reachability, compatibility and convenience. The characteristics of mobile payments are not supported because users cannot experience the benefits. Trust is not supported because not all users trust GOPAY, especially in the process of topping up balances and receiving cashback after making payment transactions. Security and privacy is not supported because users do not trust GOPAY regarding topping up balances, if the balance does not come in, they can contact the bank.
\end{abstract}

Keywords: Mobile Payment characteristics, privacy, security,Technology Acceptance Model, Trust,

\section{PENDAHULUAN}

Perkembangan mobile payment di kehidupan masyarakat semakin meningkat karena penggunaan perangkat seluler juga meningkat (Ginting, 2017). Sejak tahun 2009 Bank Indonesia sudah mendukung Gerakan Nasional Non Tunai (GNTNT) (Bank Indonesia 2020). Sistem pembayaran non tunai menggunakan perangkat seluler, (Wibawa, 2019). Salah satu aplikasi yang mendukung transaksi pembayaran non tunai adalah GOPAY, yang diperkenalkan Oktober 2010 (Zulfikar,2019).

Gopay yang memberikan kemudahan kepada pengguna dalam bertransaksi seperti pembayaran jasa, pembelian makanan dan minuman, hiburan, serta pembayaran beberapa e-cormmerce di Indonesia. Aplikasi ini memiliki keunggulan adalah fasilitas proses transaksi mudah dan cepat sehingga pengguna merasa aman dari pencurian dan penipuan, sedangkan kelemahan GOPAY adalah pengguna bergantung pada jaringan komunikasi (sinyal) yang stabil dalam pembayaran(Goenawan, 2018).

\section{STUDI LITERATUR}


Owner: Riset \& Jurnal Akuntansi

e-ISSN : 2548-9224 |p-ISSN : 2548-7507

Volume 5 Nomor 1, Februari 2021

DOI : https://doi.org/10.33395/owner.v5i1.357

Marangunic dan Andrina (2014) Technology Acceptance Model (TAM) merupakan salah satu model yang dibangun untuk menganalisis dan memahami faktor penentu penerima teknologi, menjelaskan tingkah laku pemakai akhir (end-user) teknologi informasi dengan variasi dan populasi pemakai. (Adiningsih, 2019) mobile payment merupakan sarana untuk membayar transaksi antara dua pihak dengan praktis, sederhana, aman, nyaman, simpel yang bisa dipakai dimana saja dan kapan saja dengan menggunakan perangkat selular. Dorodulu (2016), jika terdapat teknologi yang bisa bekerja dimana saja, maka penggunaannya akan meningkat atau tertarik dengan teknologi tersebut. Genady (2018), apabila orang dapat memakai suatu teknologi dimana saja dan kapan saja maka dapat meningkatkan keinginan untuk memakai teknologi itu. Amelia (2019), suatu teknologi apabila mudah diakses maka dapat meningkatkan kinerjanya serta meningkatkan keinginan seseorang untuk memakai teknologi itu. (Genady, 2018), jika pelayanan suatu teknologi bisa diakses pengguna maka pengguna mendapatkan kemudahan pemakainya. Nugroho (2017), jika mobile payment bisa diadaptasi dengan baik oleh pemakainya, maka menjadikannya bermanfaat dalam pekerjaan pemakainya. Kim, dkk (2009), jika sistem bisa dicocokkan dengan kegiatan, maka dapat memudahkan pekerjaan pemakainya Kim, dkk (2009), jika kenyamanan dirasakan pada suatu sistem maka menjadikan kinerja penggunanya meningkat. Kim, dkk (2009), keyakinan teknologi yang nyaman digunakan dapat menjadikan pekerjaan penggunanya mudah. Usman (2017), jika suatu teknologi mudah penggunaannya maka bermanfaat untuk penggunanya. Yogananda (2017), sikap yang positif ditunjukkan oleh pengguna sistem, apabila performa penggunanya ditingkatkan denegan menggunakan sistem tersebut. Yogananda (2017), suatu sistem menentukan sikap penggunanya berdasarkan apabila aktivitas pengguna dipermudah dengan sistem tersebut. Davis (2014), jika suatu sistem ada manfaatnya maka berdampak pada niat pengguna untuk pemakai sistem itu. Amelia (2019), jika pengguna merasakan adanya kemudahan dengan menggunakan suatu teknologi bagi hidupnya maka menjadikan hal tersebut sebagai niat untuk memakai teknologi itu. Ispriandina dan Mamun (2019), sikap seseorang yang positif dengan teknologi maka mempengaruhi minat seseorang tersebut. Bukhori (2018), penilaian positif akan diberikan seseorang atas suatu teknologi jika terdapat keamanan pada teknologi itu berupa tidak adanya penipuan dan pencurian. Genady (2018) sikap yang ditunjukkan pengguna suatu teknologi berdasarkan jika teknologi itu dapat dipercaya. Nugroho (2017), jika terdapat kepercayaan pengguna suatu teknologi maka terdapat niat pengguna untuk memakai teknologi itu. Nugroho (2017), suatu sistem yang mudah dapat mempengaruhi kepercayaan penggunanya. Davis (2014), kepercayaan pengguna terhadap suatu sistem dapat menjadikan kegiatan pengguna meningkat juga.

\section{Kerangka Konseptual}

Kerangka konseptual menggambarkan pengaruh antara setiap variabel yang diuji. Permasalahan dan landasan teoritis yang diurai, maka kerangka konseptual penelitian ini dilihat gambar 1.

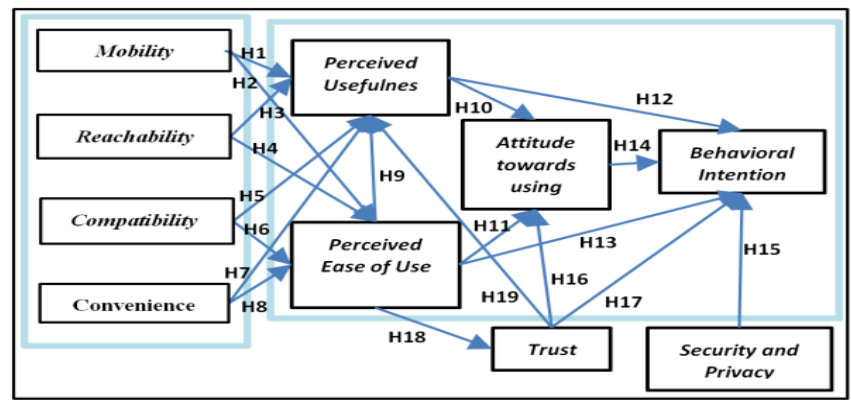

Gambar 1. Kerangka Konseptual

Sumber: Data Penelitian (2020)

H1 : $\quad$ Mobility memiliki pengaruh terhadap perceived usefulness

$\mathrm{H} 2$ : Mobility memiliki pengaruh terhadap perceived ease of use 
Owner: Riset \& Jurnal Akuntansi

e-ISSN : 2548-9224 | p-ISSN : 2548-7507

Volume 5 Nomor 1, Februari 2021

DOI : https://doi.org/10.33395/owner.v5i1.357

H3 : Reachability memiliki pengaruh terhadap perceived usefulness

H4 : $\quad$ Reachability memiliki pengaruh terhadap perceived ease of use

H5 : Compatibility memiliki pengaruh terhadap perceived usefulness

H6 : Compatibility memiliki pengaruh terhadap perceived ease of use

H7 : Convenience memiliki pengaruh terhadap perceived usefulness

H8: $\quad$ Convenience memiliki pengaruh terhadap perceived ease of use

H9 : $\quad$ Perceived ease of use memiliki pengaruh terhadap perceived usefulness

H10: Perceived usefulness memiliki pengaruh terhadapattitude toward using

H11: Perceived ease of use memiliki pengaruh terhadap attitude toward using

H12: Perceived usefulness memiliki pengaruh terhadap behavioral intention

H13 : Perceived ease of use memiliki pengaruh terhadap behavioral intention

H14 : Attitude toward using memiliki pengaruh terhadap behavioral intention

H15 : Security and privacy memiliki pengaruh terhadap attitude toward using

H16 : Trust memiliki pengaruh terhadap attitude toward using

H17 : Trust memiliki pengaruh terhadap behavioral intention

H18: Perceived ease of use memiliki pengaruh terhadap trust

H19: Trust memiliki pengaruh terhadap perceived usefulness

\section{METODE}

Penelitian ini menggunakan metode penelitian survei yaitu penelitian yang sumber data dan informasinya didapatkan dari responden dengan memakai kuesioner atau angket sebagai cara pengumpulan data dan sampel.Populasi penelitian ini adalah mahasiswa Universitas Prima Indonesia Fakultas Ekonomi angkatan 2019 sebanyak 498 orang. Sampel yang diambil adalah sebanyak 222 orang dimana data tersebut sudah sesuai dengan kriteria yang peneliti tentukan dilihat tabel 1 .

Tabel 1. Karakteristik Responden

\begin{tabular}{|c|c|c|c|}
\hline \multicolumn{2}{|c|}{ Keterangan } & \multicolumn{2}{|c|}{ Responden (orang)|Presentase (\%) } \\
\hline \multirow{2}{*}{ Jenis Kelamin } & Laki-laki & 81 & 36.5 \\
\hline & Perempuan & 141 & 63.5 \\
\hline \multicolumn{2}{|l|}{ Total } & 222 & 100 \\
\hline \multirow{4}{*}{ Usia } & 18 tahun & 11 & 4.6 \\
\hline & 19 tahun & 134 & 63 \\
\hline & 20 tahun & 74 & 31.1 \\
\hline & 21 tahun & 3 & 1.3 \\
\hline \multicolumn{2}{|l|}{ Total } & 222 & 100 \\
\hline \multirow{4}{*}{$\begin{array}{c}\text { Pernah Menggunakan } \\
\text { GOPAY }\end{array}$} & $>9$ kali & 155 & 65.1 \\
\hline & 7-9 kali & 12 & 5 \\
\hline & 4-6 kali & 25 & 10.5 \\
\hline & 1-3 kali & 30 & 19.3 \\
\hline \multicolumn{2}{|l|}{ Total } & 222 & 100 \\
\hline
\end{tabular}

Sumber: Data Olahan Kuesioner Online (2020)

HASIL

Konstruk penelitian meliputi mobile payment characteristic (mobility, reachbility, compatibility dan convenience, Technology Acceptance Model (TAM) (Perceived Usefulness (PU), Perceived Ease Of Use (PEOU), Attitude Toward Using (ATU) dan Behavioral Intention (BI)), trust (T) dan Security and Privacy (SP).Hasil output analisis deskriptif dilihat tabel 2.

Tabel 2. Hasil Output Analisis Deskriptif

\begin{tabular}{|l|l|l|l|l|}
\hline Konstruk & Missing & Mean & Modus & Std Deviation \\
\hline
\end{tabular}


Owner: Riset \& Jurnal Akuntansi

e-ISSN : 2548-9224 | p-ISSN : 2548-7507

Volume 5 Nomor 1, Februari 2021

DOI : https://doi.org/10.33395/owner.v5i1.357

\begin{tabular}{|l|c|c|c|c|}
\hline PU1 & 0 & 3.60 & 4 & 0.50 \\
\hline PU2 & 0 & 3.59 & 4 & 0.51 \\
\hline PU3 & 0 & 3.58 & 4 & 0.54 \\
\hline PU4 & 0 & 3.53 & 4 & 0.53 \\
\hline PEOU1 & 0 & 3.61 & 4 & 0.51 \\
\hline PEOU2 & 0 & 3.52 & 4 & 0.61 \\
\hline PEOU3 & 0 & 3.61 & 4 & 0.54 \\
\hline PEOU4 & 0 & 3.57 & 4 & 0.53 \\
\hline ATU1 & 0 & 3.57 & 4 & 0.53 \\
\hline ATU2 & 0 & 3.60 & 4 & 0.53 \\
\hline ATU3 & 0 & 3.57 & 4 & 0.58 \\
\hline BI 1 & 0 & 3.50 & 4 & 0.63 \\
\hline BI2 & 0 & 3.54 & 4 & 0.57 \\
\hline MOB1 & 0 & 3.64 & 4 & 0.54 \\
\hline MOB2 & 0 & 3.61 & 4 & 0.58 \\
\hline MOB3 & 0 & 3.55 & 4 & 0.61 \\
\hline REACH1 & 0 & 3.54 & 4 & 0.57 \\
\hline REACH2 & 0 & 3.57 & 4 & 0.56 \\
\hline COMP1 & 0 & 3.57 & 4 & 0.56 \\
\hline COMP2 & 0 & 3.60 & 4 & 0.53 \\
\hline COMP3 & 0 & 3.60 & 4 & 0.53 \\
\hline CONV1 & 0 & 3.58 & 4 & 0.52 \\
\hline CONV2 & 0 & 3.58 & 4 & 0.54 \\
\hline CONV3 & 0 & 3.60 & 4 & 0.58 \\
\hline CONV4 & 0 & 3.61 & 4 & 0.53 \\
\hline T1 & 0 & 3.60 & 4 & 0.53 \\
\hline T2 & 0 & 3.56 & 4 & 0.53 \\
\hline T3 & 0 & 3.58 & 4 & 0.54 \\
\hline T4 & 0 & 3.56 & 4 & 0.56 \\
\hline S1 & 0 & 3.64 & 4 & 0.48 \\
\hline S2 & 0 & 3.59 & 4 & 0.53 \\
\hline S3 & 0 & 3.64 & 4 & 0.5 \\
\hline S4 & 0 & 3.60 & 4 & 0.55 \\
\hline Kuesione 0 & $0(2020)$ & & \\
\hline
\end{tabular}

Sumber: Data Olahan Kuesioner Online (2020)

Nilai sering muncul (modus) adalah 4 artinya sangat setuju. Standar deviasi konstruk penelitian ini adalah peningkatan nilai standar deviasi yang tinggi maka semakin lebar rentang variasi datanya dan sebaliknya.

\section{Analisis Data}

Analisis data responden pengguna aplikasi GOPAY Mahasiswa Universitas Prima Indonesia Fakultas Ekonomi Angkatan 2019 menggunakan model Partial Least Square (PLS) dengan mengevaluasi outer model dan inner model.

\section{Outer Model (Model Pengukuran)}

\section{Uji Validitas Konvergen}

Uji validitas konvergen konstruk reponden pengguna aplikasi GOPAY Mahasiswa Universitas Prima Indonesia Fakultas Ekonomi Angkatan 2019 dilihat dari nilai factor loading pada Tabel 3. Setiap konstruk mobile payment characteristic, Technology Acceptance Model (TAM), trust dan konstruk security and privacy dapat dikatakan valid yang dilihat nilai factor loading besar dari 0.7 . 
Owner: Riset \& Jurnal Akuntansi

e-ISSN : 2548-9224 |p-ISSN : 2548-7507

Volume 5 Nomor 1, Februari 2021

DOI : https://doi.org/10.33395/owner.v5i1.357

Tabel 3. Nilai Factor Loading

\begin{tabular}{|l|l|}
\hline \multicolumn{1}{|c|}{ Konstruk } & \multicolumn{1}{c|}{$\begin{array}{c}\text { Factor } \\
\text { Loading }\end{array}$} \\
\hline MOB1 & 0.91 \\
\hline MOB2 & 0.9 \\
\hline MOB3 & 0.87 \\
\hline REACH1 & 0.9 \\
\hline REACH2 & 0.89 \\
\hline COMP1 & 0.9 \\
\hline COMP2 & 0.87 \\
\hline COMP3 & 0.9 \\
\hline CONV1 & 0.89 \\
\hline CONV2 & 0.92 \\
\hline CONV3 & 0.88 \\
\hline S
\end{tabular}

\begin{tabular}{|l|c|}
\hline \multicolumn{1}{|c|}{ Konstruk } & $\begin{array}{c}\text { Factor } \\
\text { Loading }\end{array}$ \\
\hline CONV4 & 0.78 \\
\hline PU1 & 0.89 \\
\hline PU2 & 0.89 \\
\hline PU3 & 0.89 \\
\hline PU4 & 0.87 \\
\hline PEOU1 & 0.86 \\
\hline PEOU2 & 0.82 \\
\hline PEOU3 & 0.82 \\
\hline PEOU4 & 0.81 \\
\hline ATU1 & 0.84 \\
\hline ATU2 & 0.86 \\
\hline
\end{tabular}

\begin{tabular}{|l|l|}
\hline \multicolumn{1}{|c|}{ Konstruk } & $\begin{array}{c}\text { Factor } \\
\text { Loading }\end{array}$ \\
\hline ATU3 & 0.86 \\
\hline BI1 & 0.93 \\
\hline BI2 & 0.93 \\
\hline SP1 & 0.87 \\
\hline SP2 & 0.87 \\
\hline SP3 & 0.87 \\
\hline SP4 & 0.87 \\
\hline T1 & 0.89 \\
\hline T2 & 0.91 \\
\hline T3 & 0.9 \\
\hline T4 & 0.89 \\
\hline
\end{tabular}

Sumber: Data Olahan Kuesioner Online (2020)

\section{Uji Validitas Diskriminan}

Uji validitas diskriminan konvergen konstruk reponden pengguna aplikasi GOPAY Mahasiswa Universitas Prima Indonesia Fakultas Ekonomi Angkatan 2019 dilihat Tabel 4.

Tabel 4. Nilai Average Variance Extracted

\begin{tabular}{|c|c|c|c|c|c|c|c|c|c|c|}
\hline Konstruk & ATU & BI & COMP & CONV & MOB & PEOU & PU & REACH & SP & T \\
\hline ATU & $\mathbf{0 . 8 5}$ & & & & & & & & & \\
\hline BI & 0.71 & $\mathbf{0 . 9 3}$ & & & & & & & & \\
\hline COMP & 0.74 & 0.64 & $\mathbf{0 . 8 9}$ & & & & & & & \\
\hline CONV & 0.77 & 0.77 & 0.79 & $\mathbf{0 . 8 6}$ & & & & & & \\
\hline MOB & 0.79 & 0.67 & 0.70 & 0.78 & $\mathbf{0 . 8 9}$ & & & & & \\
\hline PEOU & 0.77 & 0.74 & 0.72 & 0.72 & 0.64 & $\mathbf{0 . 8 2}$ & & & & \\
\hline PU & 0.74 & 0.70 & 0.66 & 0.68 & 0.64 & 0.88 & $\mathbf{0 . 8 8}$ & & & \\
\hline REACH & 0.76 & 0.89 & 0.83 & 0.80 & 0.72 & 0.74 & 0.69 & $\mathbf{0 . 8 9}$ & & \\
\hline SP & 0.69 & 0.69 & 0.77 & 0.75 & 0.66 & 0.67 & 0.65 & 0.77 & $\mathbf{0 . 8 7}$ & \\
\hline $\boldsymbol{T}$ & 0.68 & 0.63 & 0.73 & 0.72 & 0.59 & 0.69 & 0.37 & 0.73 & 0.84 & $\mathbf{0 . 8 9}$ \\
\hline
\end{tabular}

Sumber: Data Olahan Kuesioner Online (2020)

Berdasarkan Tabel 4, setiap konstruk mobile payment characteristic (mobility, reachability, compatibility dan convenience), konstruk Technology Acceptance Model (TAM) (Perceived usefulness, Perceived ease of use, Attitude toward using dan Behavioral intention), konstruk trust dan konstruk security and privacy mempunyai nilai validitas diskriminan AVE lebihbesar 5 daripada korelasi antar konstruk dengan konstruk lainnya dalam model.

\section{Uji Reliabilitas}

Uji reliabilitas menggunakan dua metode yaitu cronbach's alpha dan composite reliability. Uji reliabilitas konstruk responden pengguna aplikasi GOPAY Mahasiswa Universitas Prima Indonesia Indonesia Fakultas Ekonomi Angkatan 2019 dilihat Tabel 5.

Tabel 5. Nilai Cronbach's Alpha dan Composite Reliability

\begin{tabular}{|l|c|c|c|c|c|c|c|c|c|c|}
\hline \multicolumn{1}{|c|}{ Konstruk } & ATU & BI & COMP & CONV & MOB & PEOU & PU & REACH & SP & T \\
\hline Composite reliability & 0.91 & 0.93 & 0.92 & 0.93 & 0.92 & 0.91 & 0.94 & 0.8 & 0.92 & 0.95 \\
\hline Cronbach's alpha & 0.86 & 0.84 & 0.87 & 0.89 & 0.87 & 0.86 & 0.91 & 0.52 & 0.89 & 0.94 \\
\hline
\end{tabular}

Sumber: Data Olahan Kuesioner Online (2020)

Berdasarkan Tabel 5, hasil uji realibitas setiap konstruk responden pengguna aplikasi GOPAY mahasiswa Universitas Prima Indonesia Fakultas Ekonomi angkatan 2019 mempunyai 
Owner: Riset \& Jurnal Akuntansi

e-ISSN : 2548-9224 | p-ISSN : 2548-7507

Volume 5 Nomor 1, Februari 2021

DOI : https://doi.org/10.33395/owner.v5i1.357

nilai composite reliability besar 0.7 , namun pada nilai cronbach's alpha terdapat satu konstruk (REACH yaitu reachability) yang tidak reliablememiliki nilai kecil 0,7. Nilai composite reliability lebih baik digunakan dalam teknik PLS dibandingkan cronbach's alpha (Abdillah dan Jogiyanto, 2015).

\section{Inner Model (Model Struktural) \\ R-Square}

Nilai R-square konstruk responden pengguna aplikasi GOPAY Mahasiswa Universitas Prima Indonesia Fakultas Ekonomi Angkatan 2019 dilihat Tabel 6.

Tabel 6. Nilai R-square \begin{tabular}{|l|l|l|l|l|}
\hline Konstruk ATU & BI & PEOU & PU & T \\
\hline
\end{tabular}

\begin{tabular}{|l|l|l|l|l|l|l|}
\hline $\boldsymbol{R}$ Square & 0.64 & 0.54 & 0.60 & 0.58 & 0.35 \\
\hline
\end{tabular}

Sumber: Data Olahan Kuesioner Online (2020)

Berdasarkan Tabel 6, konstruk ATU (Attitude Toward Using) mempunyai nilai R square sebesar 0,64 artinya 64 persen konstruk mobility, reachability, compatibility, convenience dan security and privacy memiliki pengaruh terhadap Attitude Toward Using dan sisanya faktor -faktor lain yang mempengaruhinya sebesar 36 persen. Kedua, Konstruk Behavioral Intention (BI) mempunyai nilai R-square sebesar 0,54 artinya 54 persen konstruk mobility, reachability, compatibility, convenience dan security and privacy memiliki pengaruh terhadap behavioral intention dan sisanya faktor-faktor lain yang mempengaruhinya sebesar 46 persen. Ketiga, PEOU(Perceived Ease Of Use) mempunyai nilai R- square sebesar 0,60 artinya 60 persen konstruk mobility, reachability, compatibility, convenience dan security and privacy memiliki pengaruh terhadap perceived ease of use dansisanya faktor-faktor lain yang mempengaruhinya sebesar 40 persen. Keempat, konstruk Perceived Usefulness (PU) mempunyai nilai R-square sebesar 0,58 artinya 58 persen konstruk mobility, reachability, compatibility, convenience dan security and privacy memiliki pengaruh terhadap perceived usefulness dan sisanya faktor-faktor lain yang mempengaruhi sebesar 42 persen. Kelima, konstruk T (Trust) mempunyai nilai R-square sebesar 0,35 berarti 35 persen konstruk mobility, reachability, compatibility, convenience dan security and privacy memiliki pengaruh terhadap perceived usefulness dan sisanya faktor - faktor lain yang mempengaruhinya sebesar 65 persen.

\section{Nilai Koefisien Path}

Nilai Koefisien Path konstruk responden pengguna aplikasi GOPAY Mahasiswa Universitas Prima Indonesia Fakultas Ekonomi Angkatan 2019 dilihat Tabel 7.

Tabel 7. Hasil Total Effect

\begin{tabular}{|c|c|c|c|c|c|c|}
\hline & \multirow{2}{*}{$\begin{array}{c}\text { Original } \\
\text { Sample } \\
\text { (O) }\end{array}$} & \multirow{2}{*}{$\begin{array}{c}\text { Sample } \\
\text { Mean (M) }\end{array}$} & \multirow{2}{*}{$\begin{array}{l}\text { Standard } \\
\text { Error } \\
\text { (STERR) } \\
\end{array}$} & \multirow{2}{*}{$\begin{array}{c}\text { T-statistics } \\
\text { (O/STERR) }\end{array}$} & \multirow[b]{2}{*}{$\begin{array}{c}\text { P- } \\
\text { Values }\end{array}$} & \\
\hline & & & & & & \\
\hline $\mathrm{M}-\mathrm{PU}$ & 0.12 & 0.11 & 0.07 & 1.68 & 0.09 & $\mathrm{X}$ \\
\hline $\mathrm{M}-\mathrm{PEOU}$ & 0.08 & 0.08 & 0.10 & 0.78 & 0.43 & $\mathrm{X}$ \\
\hline REACH - PU & 0.05 & 0.04 & 0.08 & 0.59 & 0.56 & $\mathrm{X}$ \\
\hline REACH - PEOU & 0.32 & 0.30 & 0.12 & 2.62 & 0.01 & $\mathrm{~V}$ \\
\hline COMP - PU & -0.08 & -0.04 & 0.13 & 0.58 & 0.56 & $\mathrm{X}$ \\
\hline COMP - PEOU & 0.24 & 0.27 & 0.12 & 2.04 & 0.04 & $\mathrm{~V}$ \\
\hline CONV - PU & 0.03 & 0.02 & 0.09 & 0.31 & 0.76 & $\mathrm{X}$ \\
\hline CONV - PEOU & 0.21 & 0.21 & 0.13 & 1.65 & 0.10 & $\mathrm{X}$ \\
\hline PEOU - PU & 0.79 & 0.78 & 0.07 & 11.10 & 0.00 & $\mathrm{~V}$ \\
\hline PU - ATU & 0.22 & 0.20 & 0.13 & 1.75 & 0.08 & $\mathrm{X}$ \\
\hline
\end{tabular}


Owner: Riset \& Jurnal Akuntansi

e-ISSN : 2548-9224 |p-ISSN : 2548-7507

Volume 5 Nomor 1, Februari 2021

DOI : https://doi.org/10.33395/owner.v5i1.357

\begin{tabular}{|l|c|c|c|c|c|c|}
\hline PEOU - ATU & 0.35 & 0.36 & 0.12 & 2.95 & 0.00 & $\mathrm{~V}$ \\
\hline PU - BI & 0.12 & 0.11 & 0.13 & 0.93 & 0.36 & $\mathrm{X}$ \\
\hline PEOU - BI & 0.32 & 0.32 & 0.14 & 2.28 & 0.02 & $\mathrm{~V}$ \\
\hline ATU - BI & 0.29 & 0.29 & 0.13 & 2.28 & 0.02 & $\mathrm{~V}$ \\
\hline SP - ATU & 0.18 & 0.20 & 0.13 & 1.41 & 0.16 & $\mathrm{X}$ \\
\hline $\mathrm{T}-\mathrm{ATU}$ & 0.16 & 0.14 & 0.13 & 1.17 & 0.24 & $\mathrm{X}$ \\
\hline $\mathrm{T}-\mathrm{BI}$ & 0.13 & 0.15 & 0.10 & 1.39 & 0.17 & $\mathrm{X}$ \\
\hline PEOU - T & 0.69 & 0.69 & 0.05 & 12.71 & 0.00 & $\mathrm{~V}$ \\
\hline $\mathrm{T}-\mathrm{PU}$ & 0.02 & 0.03 & 0.07 & 0.34 & 0.73 & $\mathrm{X}$ \\
\hline
\end{tabular}

Keterangan $: \mathrm{v}=$ terdukung $\mathrm{x}=$ tidak terdukung

Sumber: Data Olahan Kuesioner Online (2020)

Berdasarkan Tabel 7, Karakteristik mobility tidak terdukung dikarenakan pengguna tidak merasakan manfaat, kemudahan, sikap positif menggunakan GOPAY di mana dan kapan saja. Karakteristik reachability, GOPAY memiliki kelemahan yaitu sinyal yang tidak stabil sehingga proses transaksi gagal. Karakteristik compatibility, pengguna GOPAY tidak memerlukan uang tunai dalam proses transaksinya dirasa efektif dan efisien. Karakteristik convenience tidak terdukung karena proses transaksi GOPAY memerlukan alat perantara mesin edc yang mengharuskan pengguna datang langsung ke merchant. Konstruk trust tidak terdukung karena kepercayaan pengguna terhadap GOPAY saat top up saldo kedalam akun dapat bertambah saldonya namun terkait konstruk securityand privasi tidak terdukung dikarenakan pengguna jika gagal top up saldo maka harus menghubungi pihak customer service GOPAY.

\section{PEMBAHASAN}

H1 : $\quad$ Mobility memiliki pengaruh terhadap perceived usefulness

Hasil dari pengolahan data $\mathrm{t}$ hitung sebesar 1,68 $<\mathrm{t}$ tabel 1,96 maka hipotesis satu tidak terdukung artinya mobility tidak memiliki pengaruh terhadap perceived usefulnes. Sejalan dengan teori menurut Dorodulu (2016), jika terdapat teknologi yang bisa bekerja dimana saja, maka penggunaannya akan meningkat atau tertarik dengan teknologi tersebut. Hasil dari penelitian sebelumnya yang diulas, hal ini GOPAY memiliki kekurangan tidak efektif dan efisien digunakan karena masih sedikit 15 merchant yang bekerja sama dengan GOPAY

$\mathrm{H} 2$ : $\quad$ Mobility memiliki pengaruh terhadap perceived ease of use

Hasil dari pengolahan data $\mathrm{t}$ hitung sebesar 0,78 $<\mathrm{t}$ tabel 1,96 maka hipotesis dua tidak terdukung artinya mobility tidak memiliki pengaruh terhadap perceived ease of use. Sejalan dengan teori menurut Genady (2018), apabila orang dapat memakai suatu teknologi dimana saja dan kapan saja maka dapat meningkatkan keinginan untuk memakai teknologi itu.Hasil dari penelitian sebelumnya yang diulas, transaksi melalui GOPAY saat ini masih memerlukan nomor perangkat seluler untuk dimasukkan ke mesin EDC sehingga pengguna merasakan kuran efektif.

H3 : Reachability memiliki pengaruh terhadap perceived usefulness

Hasil dari pengolahan data $\mathrm{t}$ hitung sebesar 0,59 < $\mathrm{t}$ tabel 1,96 maka hipotesis tiga tidak terdukung artinya reachability tidak memiliki pengaruh terhadap perceived usefulness. Sejalan dengan teori menurut Amelia (2019), suatu teknologi apabila mudah diakses maka dapat meningkatkan kinerjanya serta meningkatkan keinginan seseorang untuk memakai teknologi itu. Hasil dari penelitian sebelumnya yang diulas transaksi yang dilakukan menggunakan GOPAY berhasil maka memerlukan jaringan komunikasi ( signal ) yang stabil. jaringan komunikasi yang tidak stabil membuat pengguna GOPAY tidak merasakan manfaatnya.

H4 : Reachability memiliki pengaruh terhadap perceived ease of use 
Hasil dari pengolahan data $\mathrm{t}$ hitung sebesar $0,31<\mathrm{t}$ tabel 1,96 maka hipotesis empat terdukung artinya reachability memiliki pengaruh terhadap perceived ease of use. Sejalan dengan teori menurut Genady (2018), Jika pelayanan suatu teknologi bisa diakses pengguna maka pengguna mendapatkan kemudahan pemakainya. Hasil dari penelitian sebelumnya yang diulas, transaksi yang menggunakan GOPAY mudah dilakukan melalui perangkat seluler.

H5 : Compatibility tidak memiliki pengaruh terhadap perceived usefulness

Hasil dari pengolahan data $t$ hitung sebesar 0,58 < t tabel 1,96 maka hipotesis lima terdukung artinya compatibility tidak memiliki pengaruh terhadap perceived usefulness. Sejalan teori menurut Nugroho (2017), jika mobile payment bisa diadaptasi dengan baik oleh pemakainya, maka menjadikannya bermanfaat dalam pekerjaan pemakainya. Hasil dari penelitian sebelumnya yang diulas, teknologi menggunakan GOPAY tidak memberikan manfaat kepada penggunanya dengan kebutuhan sehari-hari.

H6 : Compatibility memiliki pengaruh terhadap perceived ease of use Hasil dari pengolahan data $t$ hitung sebesar 2,04 > t tabel 1,96 maka hipotesis enam terdukung artinya compatibility memiliki pengaruh terhadap perceived ease of use. Sejalan teori menurut Menurut Kim(2009), jika sistem bisa dicocokkan dengan kegiatan, maka dapat memudahkan pekerjaan pemakainya. Hasil dari penelitian sebelumnya yang diulas, menunjukkan penggunaan GOPAY mudah dipahami bagi penggunanya.

H7 : Convenience tidak berpengaruh terhadap perceived usefulness

Hasil dari pengolahan data t hitung sebesar 0,58 < t tabel 1,96 maka hipotesis tujuh tidak terdukung artinya convenience tidak memiliki pengaruh terhadap perceived usefulness. Sejalan teori menurut Kim(2009), jika kenyamanan dirasakan pada suatu sistem maka menjadikan kinerja penggunanya meningkat. Hasil dari penelitian sebelumnya yang diulas, pengguna merasakan ketidaknyamanan dalam transaksi menggunakan GOPAY dikarenakan penguna harus langsung datang ke merchantnya langsung.

H8 : Convenience tidak memiliki pengaruh terhadap perceived ease of use

Hasil dari pengolahan data $t$ hitung sebesar 1,65 < t tabel 1,96 maka hipotesis delapan tidak terdukung artinya convenience tidak memiliki pengaruh terhadap perceived ease of use. Sejalan teori menurut Menurut Kim(2009), keyakinan teknologi yang nyaman digunakan dapat menjadikan pekerjaan penggunanya mudah Hasil dari penelitian sebelumnya yang diulas, hal ini disebabkan sebelum melakukan transaksi perlu top up saldo terlebih dahulu sehingga membuat pengguna tidak nyaman.

H9: $\quad$ Perceived ease of use memiliki pengaruh terhadap perceived usefulness

Hasil dari pengolahan data t hitung sebesar 11,10>t tabel 1,96 maka hipotesis sembilan terdukung artinya perceived ease of use memiliki pengaruh terhadap perceived usefulness. Sejalan teori menurut Usman (2017), jika suatu teknologi mudah penggunaannya maka bermanfaat untuk penggunanya. Hasil dari penelitian sebelumnya yang diulas, penggunaan GOPAY yang mudah dilakukan sehingga meningkatkan efektivitas dan produktivitas penggunanya. Penggunaan GOPAY melalui perangkat seluler merasakan manfaatnya karena pengguna tidak perlu membawa uang tunai.

H10 : Perceived usefulness tidak memiliki pengaruh terhadapattitude toward using Hasil dari pengolahan data $t$ hitung sebesar 1,75 < t tabel 1,96 maka hipotesis sepuluh tidak terdukung artinya perceived usefulness tidak memiliki pengaruh terhadap attitude toward using. Sejalan teori menurut Yogananda (2017), sikap yang positif ditunjukkan oleh pengguna sistem, apabila performa penggunanya ditingkatkan denegan menggunakan sistem tersebut. Hasil dari penelitian sebelumnya yang diulas, Penggunaan GOPAY mempengaruhi sikapnya dalam proses transaksi yang menggunakan perangkat seluler.

H11: Perceived ease of use memiliki pengaruh terhadap attitude toward using Hasil dari pengolahan data $\mathrm{t}$ hitung sebesar 2,95 > t tabel 1,96 maka hipotesis sebelas 
terdukung artinya perceived ease of use memiliki pengaruh terhadap attitude toward using. Sejalan teori menurut Menurut Yogananda (2017), suatu sistem menentukan sikap penggunanya berdasarkan apabila aktivitas pengguna dipermudah dengan sistem tersebut. Hasil dari penelitian sebelumnya yang diulas, penggunanya memiliki kemauan menggunakan GOPAY apabila GOPAY memiliki kemudahan pengunaanya.

H12: Perceived usefulness tidak memiliki pengaruh terhadap behavioral intention

Hasil dari pengolahan data $\mathrm{t}$ hitung sebesar 0,93 < tabel 1,96 maka hipotesis dua belas tidak terdukung artinya perceived usefulness tidak memiliki pengaruh terhadap attitude toward using. Sejalan teori menurut Menurut Davis (2014), jika suatu sistem ada manfaatnya maka berdampak pada niat pengguna untuk pemakai sistem itu. Hasil dari penelitian sebelumnya yang diulas, hal ini dikarenakan transaksi GOPAY tidak berlaku di beberapa merchant maka pengguna merakan tidak efektif selain itu saat pengisian saldo GOPAY dirasakan sulit.

H13 : Perceived ease of use memiliki pengaruh terhadap behavioral intention Hasil dari pengolahan data $\mathrm{t}$ hitung sebesar 2,28 > t tabel 1,96 maka hipotesis tiga belas terdukung artinya perceived ease of use memiliki pengaruh terhadap attitude toward using. Sejalan teori menurut Menurut Amelia (2019), jika pengguna merasakan adanya kemudahan dengan menggunakan suatu teknologi bagi hidupnya maka menjadikan hal tersebut sebagai niat untuk memakai teknologi itu Hasil dari penelitian sebelumnya yang diulas, kemudahan penggunaan GOPAY yang melalui perangkat seluler dapat meningkatkan peminat penggunaanya dengan promosi cashback setelah dilakukan transaksi.

H14 : Attitude toward using memiliki pengaruh terhadap behavioral intention Hasil dari pengolahan data $\mathrm{t}$ hitung sebesar 2,28 > t tabel 1,96 maka hipotesis empat belas terdukung artinya attitude toward using memiliki pengaruh terhadap behavioral intention. Sejalan teori menurut Menurut Ispriandina dan Mamun (2019), sikap seseorang yang positif dengan teknologi maka mempengaruhi minat seseorang tersebut. Hasil dari penelitian sebelumnya yang diulas, peminat penggunaan GOPAY seperti cashback yang ditawarkan oleh GOPAY setelah melakukan transaksi.

H15 : Security and privacy tidak memiliki pengaruh terhadap attitude toward using Hasil dari pengolahan data $\mathrm{t}$ hitung sebesar 1,41 < t tabel 1,96 maka hipotesis lima belas tidak terdukung artinya security and privacy tidak memiliki pengaruh terhadap attitude toward using. Sejalan teori menurut Menurut Bukhori (2018), penilaian positif akan diberikan seseorang atas suatu teknologi jika terdapat keamanan pada teknologi itu berupa tidak adanya penipuan dan pencurian. Hasil dari penelitian sebelumnya yang diulas, pengguna dapat menghubungi pihak bank yang terkait jika top up saldo tidak masuk.

H16 : Trust tidak memiliki pengaruh terhadap attitude toward using Hasil dari pengolahan data $t$ hitung sebesar 1,17 < t tabel 1,96 maka hipotesis enam belas tidak terdukung artinya trust tidak memiliki pengaruh terhadap attitude toward using. Sejalan teori menurut Genady (2018) sikap yang ditunjukkan pengguna suatu teknologi berdasarkan jika teknologi itu dapat dipercaya. Hasil dari penelitian sebelumnya yang diulas, pengguna belum percaya dalam proses top up saldo GOPAY dan menerima cashback setelah bertansaksi.

H17 : Trust tidak memiliki pengaruh terhadap behavioral intention

Hasil dari pengolahan data $\mathrm{t}$ hitung sebesar 1,39 < t tabel 1,96 maka hipotesis tujuh belas tidak terdukung artinya trust tidak memiliki pengaruh terhadap behavioral intetion. Sejalan teori menurut Nugroho (2017), jika terdapat kepercayaan pengguna suatu teknologi maka terdapat niat pengguna untuk memakai teknologi itu. Hasil dari penelitian sebelumnya yang diulas, kurang kepercayaan terhadap GOPAY yang dapat menawarkan cashback yang besar kepada pengguna dengan syarat dan ketentuan 
berlaku, hal ini membuat pengguna merasakan kesulitan untuk mendapatkannya.

H18 : Perceived ease of use memiliki pengaruh terhadap trust

Hasil dari pengolahan data thitung sebesar 12,71 > t tabel 1,96 maka hipotesis delapan belas terdukung artinya perceived ease of use memiliki pengaruh terhadap trust. Sejalan teori menurut Nugroho (2017), suatu sistem yang mudah dapat mempengaruhi kepercayaan penggunanya. Hasil dari penelitian sebelumnya yang diulas, kemudahan dalam bertransaksi dapat meningkatkan kepercayaan penggunanya menggunakan GOPAY sehingga pengguna memiliki kepercayaan terhadap teknologi GOPAY.

H19 : Trust tidak memiliki pengaruh terhadap perceived usefulness

Hasil dari pengolahan data $\mathrm{t}$ hitung sebesar 0,34 < t tabel 1,96 maka hipotesis sembilan belas tidak terdukung artinya trust tidak memiliki pengaruh terhadap perceived usefulness. Sejalan teori menurut Menurut Davis (2014), kepercayaan pengguna terhadap suatu sistem dapat menjadikan ke

giatan pengguna meningkat juga. Hasil dari penelitian sebelumnya yang diulas, hal ini pengguna merasakan kesulitan top- $u p$ saldo aplikasi GOPAY dan melakukan transaksi yang dirasakan pengguna lama dikarenakan pengguna harus memasukan nomor perangkat seluler.

\section{KESIMPULAN}

Berdasarkan hasil penelitian dapat diambil kesimpulan bahwa faktor- faktor yang mempengaruhi penerimaan dan penggunaan Mobile Payment pada teknologi pembayaran GOPAY yaitu mobile payment characteristics, trust dan security and privacy tidak terdukung dalam penelitian ini. Gopay Memiliki karateristik mobility, reachability, compatibility dan convenience. Karakteristik mobile payment tidak terdukung karena pengguna tidak merasakan manfaatnya. Trust tidak terdukung dikarenakan belum semua pengguna percaya terhadap GOPAY terutama dalam proses top up saldo dan menerima cashback setelah melakukan pembayaran. Security, privacy tidak terdukung karena pengguna belum percaya terhadap GOPAY terkait pengisian saldo, apabila saldo tidak masuk dapat menghubungi pihak bank. Pengembangan GOPAY pada mahasiswa faktor yang perlu diperhatikan adalah memperluas cakupan kerjasama merchant terutama memberikan kemudahan kepada mahasiswa dalam kebutuhan sehari-hari.

\section{REFERENSI}

Adiningsih, S. (2019). Transformasi Ekonomi Berbasis Digital Di Indonesia ; Lahirnya Tren Baru Teknologi, Bisnis Ekonomi Dan Kebijakan Di Indonesia . Jakarta: Gramedia Pustaka Utama.

Amelia, E. (2019). Analisis Perilaku Minat Menggunakan Mobile Payment Dengan Pendekatan Technology Acceptance Model (Studi Pada Pengguna Aplikasi Pembayaran OVO). Bandung: Universitas Pendidikan Indonesia.

Bank Indonesia. (2020). Informasi Perizinan Penyelenggara Dan Pendukung Jasa Sistem Pembayaran Per 12 Maret 2020. Dipetik Maret 20, 2020, dari www.bi.go.id

Bukhori. (2018). Analisis Faktor - Faktor Yang Mempengaruhi Dan Dampak Adopsi Mobile Payment Di Kalangan Merchant (Studi Kasus Fasilitasi Mocash Pada Merchant Di Kab. Pacitan). Yogyakarta: Universitas Islam Indonesia.

Davis, F. (2014). A Technology Acceptance Model For Empirically Testing New Enduser Information Systems: Theory And Results. Dipetik Mei 10, 2020, dari www.researchgate.com

Dorudulu, O. (2016). Technology Acceptance Model As A Predictor Of Using Information System To Acquine Information Literacy Skills. Dipetik Mei 10, 2020, dari www.digitalcommons.uni.edu.com 
Owner: Riset \& Jurnal Akuntansi

e-ISSN : 2548-9224 | p-ISSN : 2548-7507

Volume 5 Nomor 1, Februari 2021

DOI : https://doi.org/10.33395/owner.v5i1.357

Genady. (2018). Pengaruh Kemudahan, Kemanfaatan Dan Promosi Uang Elektronik Terhadap Keputusan Penggunaan Uang Elektronik Di Masyarakat (Studi Kasus Di Provinsi DKI Jakarta). Jakarta: Universitas Islam Negeri Syarif Hidayatullah.

Ginting, D. (2017). Komunikasi Cerdas; Panduan Komunikasi Di Dunia Kerja. Jakarta: Elex Media Komputindo.

Goenawan, G. (2018). New Money; Riba Siapa Bilang? . Jakarta: Elex Media Komputindo.

Ispriandina, \& Mamun. (2019). Faktor - Faktor Penerimaan Teknologi Yang Mempengaruhi Intensi Kontinuitas Penggunaan Mobile Wallet Di Kota Bandung. Bandung: Politeknik Negeri Bandung.

Kim, d. (2009). An Empirical EcaminationOf Factory Influencing The Intention To Use Mobile Payment. Dipetik Mei 15, 2020, dari www.elsevier.com

Marangunic, N., \& Andrina, G. (2014). Technology Acceptance Model: A Literature Review From 1986 to 2013. Dipetik Mei 05, 2020, dari www.springer.com

Nugroho. (2017). Faktor- Faktor Yang Mempengaruhi Niat Menggunakan Mobile Payment Dengan Pendekatan Extended The Unified Theory Of Acceptance And Use Of Technology. CITEE, 226-233.

Usman, R. (2017). Karakteristik Uang Elektronik Dalam Sistem Pembayaran. Yuridika Journal, 134-166.

Wibawa. (2019). Era Bisnis Online; Anak Muda VS Raksasa Bisnis. Jakarta: Pena Kopi Hitam.

Yogananda, A. (2017). Pengaruh Persepsi Manfaat, Persepsi Kemudahan Penggunaan, Kepercayaan Dan Persepsi Resiko Terhadap Minat Untuk Menggunakan Instrument Uang Elektronik. Diponegoro Journal, 1-7. 